\title{
The Vocabulary of Inanimate Nature as a Part of Turkic-Mongolian Language Commonness
}

\author{
Valentin Ivanovich Rassadin \\ Doctor of Philological Sciences, Professor, Department of the Kalmyk language and Mongolian studies \\ Director of the Mongolian and Altaistic research Scientific centre, Kalmyk State University \\ 358000, Republic of Kalmykia, Elista, Pushkin street, 11
}

Doi:10.5901/mjss.2015.v6n6s2p126

\section{Abstract}

The article deals with the problem of commonness of Turkic and Mongolian languages in the area of vocabulary; a layer of vocabulary, reflecting the inanimate nature, is subject to thorough analysis. This thematic group studies the rubrics, devoted to landscape vocabulary, different soil types, water bodies, atmospheric phenomena, celestial sphere. The material, mainly from Khalkha-Mongolian and Old Written Mongolian languages is subject to the analysis; the data from Buryat and Kalmyk languages were also included, as they were presented in these languages. The Buryat material was mainly closer to the Khalkha-Mongolian one. For comparison, the material, mainly from the Old Turkic language, showing the presence of similar words, was included; it testified about the so-called Turkic-Mongolian lexical commonness. The analysis of inner forms of these revealed common lexemes in the majority of cases allowed determining their Turkic origin, proved by wide occurrence of these lexemes in Turkic languages and Turkologists' acknowledgement of their Turkic origin. The presence of great quantity of common vocabulary, which origin is determined as Turkic, testifies about repeated ancient contacts of Mongolian and Turkic languages, taking place in historical retrospective, resulting in hybridization of Mongolian vocabulary.

Keywords: Turkic-Mongolian lexical commonness, the vocabulary of inanimate nature, landscape vocabulary, names of soil types, names of water bodies, terms of atmospheric phenomena, terms of celestial sphere, language contacts, vocabulary hybridization.

\section{Introduction}

The problem of Turkic-Mongolian linguistic connections is not new. From the XVIII century, it is being discussed in the scientific literature together with the hypothesis of the genetic affinity of so-called Altai languages, which involve, apart from Turkic and Mongolian languages, Tungus languages as well. The history of Altai investigations has a vast scientific literature, devoted to different aspects of this hypothesis, as the Turkic and Mongolian languages show the closest relations to each other from all the languages of Altai family, i.e. their commonness usually forms the basis of Altai hypothesis. Due to the fact, that there was insufficient material on Turkic and Mongolian languages in the period from XVIII to XIX and the beginning of XX centuries, and mainly Turkic sources of Arabic writing and Mongolian sources in Old Written Mongolian language were in scientists' disposal, they were far from vivid specific Turkic and Mongolian languages, then it was difficult to expect deep investigations of this problem. The native science, the same as the world one, still cannot answer the question up to the end: if the Altaic proto-language really existed, or it is a myth and the languages of inhabitants of the Central Asia became closer in high antiquity as a result of various contacts.

From the end of XIX and the beginning of XX century, the situation of previous study of Turkic and Mongolian languages became to change significantly; a lot of investigations on grammar and vocabulary of different vivid Turkic and Mongolian languages and their dialects appeared, providing a possibility to present this hypothesis from a new angle.

The investigations of such great Altai-scientists, as Ramstedt (1957a), Kotwich W. (1953), Poppe N. (1960; 1965), Doerfer G. (1963), Räsänen M. (1965) appeared in the world science; there are the works of Vladimirtsov B.Ya. (1911) in Russian science. When a number of investigations of Foreign Altai scientists was published in Russian translation, it became possible to discuss the Altai hypothesis widely. Such works, as "Introduction to Altai Linguistics" by G.I. Ramstetd (1957b), "The Investigations on Altai Languages" by V.L. Kotvich (1962), the article of A. Ron-Tash "General Heritage or Borrowing?" (To the Problem of Relations of Altai Languages)" (1974), a monograph of M. Ryasyanen (1955) and a number of other investigations were published in Russian and became available to side mass of native Turkologists and Mongolists. From the native scientists, this problem was studied by the Mongolist G.D. Sanzheev (1947; 1971; 1973), the Turkologists A.M. Shcherbak (1959a; 1959b; 1960; 1977; 2005), N.A. Baskakov (1981). 
The Leningrad Department of the Linguistics Institute of AS USSR organized the sector of Altaic languages, the members of which published the results of different investigations on the history of Turkic, Mongolian, Tungus and Korean languages. A question about more close relation of Turkic and Mongolian languages was raised and began to be developed, as well as the problem of existence of hypothetic Turkic-Mongolian proto-language. The Altai studies began to develop two opposite viewpoints on the kinship problem of not only Turkic and Mongolian languages, but also the relation of these languages with the other Altaic ones. Thus, for instance, some scientists, following G.I. Ramstedt, considered, that all revealed grammatical and lexical similarities between Altaic languages present the heritage of general Altaic proto-language. Other Altaists, following V.L. Kotwich, come to the conclusion that the Altaic grammatical and lexical commonness appeared mainly in the process of historical development of the Altaic languages due to various contacts of these languages and penetration of different mutual borrowings.

From other native investigators of Turkic-Mongolian problem, it is necessary to mention the works of such Turkologists, as Sydykov (1966; 1983), Suyunchev (1977). The article "Turkic Elements in Mongolian Language" by B.Ya. Vladimirtsov, published in 1911, was a sample for native investigators of Turkic-Mongolian linguistic problem. In connection with Turkic-Mongolian linguistic problem, it is necessary to mention our studies, devoted to the development history of Turkic-Mongolian linguistic commonness, by the example of study of both Turkic influence on the vocabulary of Mongolian languages (2007), and the Mongolian influence on some Turkic languages (2008), and also the revelation of correlation of Turkic and Mongolian grammatical elements, included to the Turkic-Mongolian linguistic commonness (2012). However, despite different studies of the interrelation problem of Turkic, Mongolian and Altaic languages in whole, they were mainly concerned with phonetics and grammar of these languages, and separate sides of vocabulary, at that, the vocabulary, being the brightest indicator of the Altaic languages, was not subject to total investigation in order to reveal all general lexical correlation between these languages. By the present moment, the native science has a lot of new investigations on the vocabulary of Turkic and Mongolian languages, providing an opportunity to reveal the TurkicMongolian lexical commonness at the higher level. On the part of Turkic-Mongolian languages, apart from "Old Turkic Dictionary" (1969), several volumes of "Etymological Dictionary of Turkic Languages" by E.V. Sevortyan and his followers (1974; 1978; 1989; 1997; 2003) appeared at the scientists' disposal, as well as the "Comparative Grammar of Turkic Languages. Vocabulary" (2001); besides, the whole range of new more complete dictionaries on many Turkic languages also appeared. On the part of Mongolian languages, when revealing general Turkic-Mongolian vocabulary, apart from generally known dictionaries of Old Written Mongolian language, such as "Mongolian-Russian-French Dictionary" by 0. Kovalevsky in three volumes (1844-1849), "Mongolian-Russian Dictionary" by K.F. Golstunsky (1894-1898), "MongolianEnglish Dictionary" by F.D. Lessing (1960), it is also helpful to refer to the "Large Academic Mongolian-Russian Dictionary" (2001-2002), which provides, apart from the forms of modern Khalkha literary language, corresponding words from the Old Written Mongolian language. The material on Buryat language is taken from the "Buryat-Russian Dictionary" by K.M. Cheremisov (1973); the material on Kalmyk language is taken from the "Kalmyk-Russian Dictionary" (1977).

Thus, it is possible to say, that there are new opportunities to collect factual comparative material from Turkic and Mongolian languages, in order to determine their lexical commonness.

Our preliminary studies of this problem show, that it is not all that simple and clear here. Modern Turkic languages are heterogeneous as for the presence of vocabulary, correlated with the Mongolian one. The major part of vocabulary, correlated with the Mongolian languages, is presented in Siberian Turkic languages, which, in virtue of historical reasons, reflect the closest relations of these languages not only with the Medieval ones, but also, later, with modern Mongolian languages and dialects, and some of these languages still continue interacting with Mongolian ones. Thus, the major part of lexical correlations with the Mongolian languages was revealed in Yakut and Tuvin languages. Little less correlations with the Mongolian languages is presented in Altaic, Khakas, Shor, Tofalar, Soyot languages, the languages of Chulym Turki and Siberian Tatars. The languages of Uigur-Tsaatan and Uigur-Uryankh, of Mongolian Kazakh are still in close contact with the Mongolian languages, and Soyots of Buryatia - with Buryat language. From Turkic languages of other areas, it is necessary to mention the Kirghiz language and the language of Kypchak group - Kazakh, Kara-Kalpak, Nogai, also having many correlations with the Mongolian languages in their vocabulary. There are also the Mongolian correlations in the language of Tatar and Bashkir, as well as in the language of Kumyk, Karachay, Balkar. The languages of Karluk group - Uzbek and Uigur - also have Mongolian correlations. At that, the languages of Uigur, living in SintszyanUigur autonomous territory of P.R. China still contact directly with modern Mongolian languages, mainly, with the language of Oyrat. The least quantity of vocabulary, common with Mongolian one, is presented in Chuvash language and in the language of Oguz group: Azerbaijani, Turkish, Turkmen and Gagauz. At that, as the Turkmen live in Central Asia, and they are historically connected with Kypchak and other Central Asian tribes, then, their language has more Mongolian correlations, than the other Oguz languages. The language of monuments of Old Turkic Writing, judging by the Old Turkic dictionary, has a lot of vocabulary, correlating with Mongolian languages, at that, the detailed consideration of 
general Turkic-Mongolian vocabulary showed, that many words of this group, presented in Mongolian languages, have firm Turkic etymology and cannot be explained from other languages; such words can be definitely referred to Turkic borrowings in Mongolian languages, penetrated in different historical periods. As these words are presented both in the language of ancient monuments, and in modern Turkic languages, and bear generally Turkic character, then they testify about more ancient relations of Mongolian languages with the Turkic ones, taking place long before the XIII century, the epoch of Mongolian emancipation, when the impact of Mongolian languages on Turkic ones was intensified.

On the other hand, the presence in some Turkic languages of some words, etymologized on the basis of Mongolian languages, allows assuming their Mongolian origin, due to definite features, characterizing these words; their penetration into different Turkic languages is connected with the impact of both Medieval and modern Mongolian languages in different historical periods. At the same time, there are some words without clear definiteness concerning their origin. In relation to semantics, this vocabulary is heterogeneous and presents different thematic groups, bearing evidence of the diversity of life situation, resulting in Turkic-Mongolian language contacts. The study of definite thematic groups of vocabulary allows specifying both character of Turkic languages, from which the borrowings were taken, and the character of region, where the contacts of Turkic and Mongolian ethnic groups took place.

\section{Main Part}

In this case, we are interested in the vocabulary of inanimate nature, having the Turkic parallels, the majority of which are of Turkic origin. Let us study these words more thoroughly below.

The Mongolian word yortonc "world, universe, space, macrocosm; light, nature" (Old Written Mongolian jirtinču, Buryat yurtemse) have the Old Turkic parallel jirtinču with the same meaning "world, universe", as this lexeme was presented in Old Uiyur texts of Buddhistic content; then, obviously, it came to Mongolian language together with the translation of Uiyur Buddhistic texts into Mongolian language in the period, when Buddhism was outspread among early Mongolian tribes long before the epoch of Chenghis Khan, i.e. somewhere in the VII-VIII centuries A.D., in the bloom period of Uighur Kaganate of the Central Asia.

The Mongolian word delkhii "world, earth, light, universe" (Old Written Mongolian delekei, Buryat delkhii, Kalmyk delkä) has constrained circulation in Turkic languages, mainly, in Siberian ones, comparing, for instance, Altaic, Shor telekei, Tuvinian delegei, it is possible to assume confidently its Mongolian origin in these languages.

The Mongolian languages are characterized by the presence of great quantity of landscape vocabulary with Turkic equivalents of clearly Turkic origin. In any case, both these words themselves and their deriving roots are recorded in Old Turkic language. Thus, the Mongolian word uul "mountain, mountains, range of mountains" (Old Written Mongolian ayula, Buryat uula, Kalmyk uul id) is not etymologized on the Mongolian basis; it is possible to try to interpret its archetype *ayula, recorded in Old Mongolian language, as lambdoiding variant of Old Turkic word form ayiiš "hill, rise", which dates back to the Old Turkic verb ay= "to raise (up), to ascend; to climb up; to uplift, to climb, to raise". It is possible to assume, that the Old Mongolian word ayur "steam" was also formed from this word; it is recorded in Old Mongolian Writing, giving origin to modern Kh.-Mongolian uur "steam, vapor, gases, air, atmosphere, spirit, breath, climate" (Buryat uur, Kalmyk uur id), although its parallel is not presented in Old Turkic language.

A Mongolian word tag "plato; mesa plate", recorded in Old Mongolian Writing, as tay with the meaning of "table land; flat topped mountain" has the Old Turkic parallel tay "mountain", widely spread in all modern Turkic languages with the same meaning (see "Comparative-Historical Grammar of Turkic languages...", p. 94, for the occurrence of this lexeme in Turkic languages and its vernacularity); this word is not recorded in other modern Mongolian languages, that is why it is possible to assume confidently the Turkic origin of this lexeme. There is a word saridag in the Mongolian language, meaning "a mountain with permanent snow cover; bald mountain", which is recorded as sariday with the same meaning in Old Written Mongolian language. This word is presented in Buryat language in the form kharidag and means "bald mountain, treeless mountain peak". There is the highest mountain with permanent snow cover in Tunkinsk region of Buryatia through the Tunkinsk mountain range; its name is Munkhe-Saridag, in Buryat Munkhe-Kharidag. The peculiarity of this mountain range is that its peaks are made of yellow rock, that is why the Turkic origin of this word becomes quite clear. The constituents of this Mongolian lexeme sariday are presented by two elements - sari and day, which can be interpreted as Turkic words sarï "yellow", day "mountain". Thus, the Mongolian sariday was initially a Turkic sarïday "yellow mountain", what is proved by the peculiarity of this realia. If to refer to the languages of Old Turkic monuments, we can see, that they have the word combination menkü qaja "eternal rock, monument with writings" (Old Turkic Dictionary, p. 343), then the Old Turkic combination menkü sarïday "eternal yellow mountain" becomes quite admissible; it gave origin to the Buryat Munkhe-Kharidag, Munkhe-Kharidag.

The Mongolian khad "rock, cliff, stony mountain" (Old Written Mongolian qada, Buryat khada id) can be compared 
with the Old Turkic qaja "rock", which is widely spread in modern Turkic languages in the same meaning (see "Comparative-Historical Grammar of Turkic languages...", p. 96, for the occurrence of this lexeme in Turkic languages and its hypothetical Mongolian origin). The intervocalic $-j$ - in this Turkic word form can be quite acceptable as a variant in the chain of Turkic alternations $j-d-z-r$, generally known in the system of Turkic languages in this position. Compare, for instance, Turkic ajaq - adaq - azaq - ura "leg", here in the case with qaja, it is not quite clear, why the variant with c -j-? became so wide spread. Thus, the Tuvinian language is d-language, and "rock" is also named khaya, the Khakas language is z-language, and "rock" is also named khaya, as well as kaya in Altai language, which belongs to j-languages.

The Mongolian khyar "spine (of hill), top, mountain range, foothill" (Buryat khyara "mountain edge") is recorded in Old Mongolian Writing as qir-a, the archetype of which is *qïra, what is quite comparable with the Old Turkic qïr "plateau, dam". (See the "Comparative-Historical Grammar of Turkic languages...", p. 95-96, for the occurrence in Turkic languages). In modern Turkic languages, qïr is known more as "the mountains with aiguilles, mountain range".

The Mongolian boom "cusp, projecting rock" (Buryat боомо yazar, Kalmyk боомо yazr "heavy-going place") is recorded in Old Mongolian Writing as boyum with the same meaning. It is possible to assume, that this Mongolian word is formed from the Mongolian verb boyu "to obstruct, to block, to cut the road, to impede", which has also a meaning "to tie, to tie up, to wrap, to pack". The second meaning of this Mongolian verb can be compared with the Old Turkic boy= "to strangle, to squash". It is possible, that the Old Turkic boyum/boyïm "knot, joint, articulation (of fingers, reed)" is derived from it. The word boom "narrow, high mountains along the shores of mountain river, as if clenching its stream", presented in some Siberian Turkic languages, can be considered as coming from the Mongolian language.

The Mongolian bulš "burial mound; tomb, cemetery, graveyard, tomb mound" (Buryat bulaša "burial ground, burial mound, tomb; cemetery ", Kalmyk buliš "tomb; vault; cemetery") was recorded in Old Mongolian Written language as bulaši with the same meaning. The inner form of this word consists of the components bula and ši, where the component $s$ si is neither more nor less than simple verbal word-formative general Mongolian affix, and the component bula can be identified with the Mongolian verb bula (the modern Mongolian bulakh, Buryat bulakha "to embed, to bury, to cover, Kalmyk bulkh "to cover, to bury, to embed, to entomb"), meaning "to bury, to cover, to embed, to fill up, to throw in", what is presented in the semantics of Mongolian bulš. This Mongolian verb can be compared with the Old Turkic bula= "steam, stew (about food)". If to take into consideration, that ancient nomads-cattle breeders, both Turki and Mongolians, widely practiced stewed meat dishes, digging them into the ground under the fire, then, the use of this Turkic verb becomes also clear in creation of the burial mound that obviously took place long ago, when the ancient Turki overruled in the steppes of Central Asia.

The Mongolian tovon "prominence" (Buryat dobuun "elevated place, hill, hillock; mound", Kalmyk dovun "hillock, prominence, elevated place") is recorded in Old Written Mongolian language as tobung with the same meaning. It is possible to compare with the Old Turkic töpü "crown, top; head; peak", compare, for instance, Old Turkic sumir taynïn töpüsintä "on the top of Sumeru mountain". Here is clear, that the meanings of Mongolian and Turkic words are within the limits of one semantic field, although there are slight differences.

The Mongolian žalya "coomb, hollow, narrow log, stria, valley; creek valley, dike; gully; cavity" (Buryat žalya "valley, stria; coomb, hollow, log, creek valley, dike", Kalmyk žaly "hollow, valley") is recorded in the Old Written Mongolian language as jily-a with the same meanings, which archetype can be *jïlya. The are two components: *jil and ya. If to assume, that -ya is a word-forming suffix, then the element * jill cannot be explained on the Mongolian basis. It can be compared with the Turkic verb $j i l=/ l j i l=$, which is traced, for instance, in the Old Turkic words jïlan "snake" jillyun "tamarisk", jïldiz "root" and means "to wriggle". The Tatar elya, Bashkir jïlya "river", based on the same Turkic verb jïl=, can be compared with the Mongolian jily-a. The similarity of meanings of Mongolian and Turkic words is in the fact, that externally and visually "the coomb, the valley" and "the river with its channel" present basically similar objects of nature. The coombs of steppe Mongolia are presented as deep serpentine grooves, along the bottom of which can flow the spring. Essentially, these grooves are formed by the rain or spring water that is why their similarity with the river is obvious.

The Mongolian tal "field, steppe, open space; side, place" (Buryat tala "field, steppe, plain, open space, Kalmyk tala "open space, field; plain") is recorded in the Old Mongolian Writing as tal-a with the same meaning. It can be compared with the Old Turkic tala "steppe" (see the "Comparative-Historical Grammar of Turkic languages...", p. 99, for the occurrence of this word in Turkic languages).

The Mongolian cecegleg "flower garden, garden" (Buryat seseglig "bloomy", Kalmyk cecglg "flower garden") is recorded in the Old Mongolian Writing as čečeglig id.). This word consists of two components: the root čečeg and affix lig. This root means the flower, and it is widely presented in modern Mongolian languages - Kh.-Mongolian ceceg, Buryat. seseg, Kalmyk cecg id. Both Mongolian components have Turkic origin. The word čeček is widely spread in modern Turkic languages, and it is presented in the language of Old Turkic monuments in the form čečäk "flower". Its genesis has 
the Turkic verb čeč= (see the "Comparative-Historical Grammar of Turkic languages...", p. 120-121, for the occurrence of this word in Turkic languages and its Turkic etymology), recorded in Old Turkic language with the meaning "to disperse, to spread". The Turkic affix -lï///lik is also generally known; it serves to form the word čečäklik "flower garden" in the Old Turkic language, which became the prototype for the Mongolian čečeglig. Obviously, the Mongolian cecerleg "garden, hotbed; flower garden" and Buryat seserlig "flower garden, rarely "flower bed" are connected with these Turkic components.

The Mongolian otor "distant pasture; cattle grazing on distant pastures; fresh grass in spring; spring round-up" (Buryat otor "summer shed, hunters lodge; summer farm; remote pasture", otorlokho "go to summer shed with cattle", Kalmyk otr "distant pasture") is given in Old Mongolian Writing as otur id. This word can be compared with the Turkic otar "pasture" (see Sevortyan..., 1974, p. 488, for the Turkic character of this word and its Turkic etymology), derived from the generally Turkic word ot "grass" (see the "Comparative-Historical Grammar of Turkic languages...", p. 119-120; Sevortyan..., 1974, p. 481, for the occurrence of this word in Turkic languages).

The Mongolian cöl "desert; desolate, unpopulated" (Buryat "sül desolate, sül yazar, sül gübi "desert", Kalmyk cöl "desert") is recorded in the Old Mongolian Writing as cool with the same meaning and can be compared with the Old Turkic čöl "desert".

The Mongolian oi "forest (usually on plain)" (Buryat oi "forest", Kalmyk $\theta \theta$ "forest") is recorded in the Old Mongolian Writing as oi "forest". Its correspondence in Old Turkic language is the word oi, means "valley" (see Sevortyan..., 1974, p. 425, for the occurrence of this word in Turkic languages and its Turkic origin). Unconformity of meaning of Mongolian and Turkic lexemes can be explained by metaphorical adjacent shift, as in the Mongolian language, this word is referred to the forest, growing on the plain, usually in the floodplain; the hilly forest is named in another way.

The Mongolian taiya "taiga, thick forest" (Buryat taiya) is recorded in Old Mongolian Writing as tayiy-a in the same meaning. Its correspondence in many Turkic languages is the word taiga, meaning either "thick, deep forest" or "hilly forest", as in Siberian Turkic languages. Meanwhile, it is difficult to say something definite about the origin of this word, as it was not recorded in the language of Old Turkic monuments. The presence of khovč in the Mongolian language, meaning "hilly forest", allows assuming, that the lexeme taiya can come to Mongolian and Buryat from Turkic languages.

The Mongolian word cavčlan "fire-break in the forest" (Buryat sabšalan "mowing", Kalmyk čavčkh "to cut, to chop"), recorded in the Old Mongolian Writing as čapčilan in the same meaning, is formed on the Mongolian basis by means of affix from the Mongolian verb čabči "to cut", which can be compared with the Old Turkic čap= "to cut", being widely spread in Turkic languages.

The Mongolian tarialan"tillage, field, cornfield, sowing» (Buryat tarialan "tillage", Kalmyk tärlyn "seeding, sowing; cornfield, field, tillage"), recorded in the Old Mongolian Writing as tarijalang with the same meaning, having the archetype *tarïyalang, where the components *tarïy and -alang are traced. At that, the component -alang presents a word-formative affix -alang and the inserted vowel -a-, used, if there is the final consonant of the deriving stem. The component *tarïy can be compared with the Old Turkic word tarïy "grain, corn, bread; millet; farming, agronomy", which genesis has the Old Turkic verb tarï= "to sow".

The Mongolian khiayt yazar "the place, overgrowing with wheat grass" (compare, Buryat khiayta yazar id.) is given in the Old Mongolian Writing as qijaytu yajar with the same meaning. The component qijaytu, having the archetype *qijaytu, which consists of two elements * qijjay and -tu. Here -tu presents the general Mongolian affix with the semantics of possession of any subject, property, feature; the component *qijay is presented in modern Mongolian language as khiay, in Buryat - as khiay with the meaning "wheat grass", being nothing more than the borrowing of the Turkic word qïyaq "wheat grass", presented in some Turkic languages, as, for instance, Bashkir qïyaq, Kirghiz qïyaq "wheat grass" and derived from the Turkic verb qïy= "to cut on the slant". The use of verb with this semantics is conditioned by that feature of the wheat grass, that it has sharp, cutting edges.

It is necessary to include the names of roads, paths etc. to the landscape vocabulary.

The Mongolian zörög "path, footpath; walk, pathway" (Buryat zürge "walk, pathway") is recorded in the Old Mongolian Writing as jörig with the same meaning. It is impossible to interpret this word on the Mongolian basis, at the same time, it can be etymologized on the Turkic basis, dating back to the Old Turkic verb jürü- // jüri "to go, to move around". This Turkic verb is also connected with the Mongolian zörlög "passing place, bifurcation; (road) cross" (Old Written Mongolian jörilge id.) and zörölt "cross road" (Old Written Mongolian jörilte id.).

The Mongolian belčir "waters meet; cross-roads; crotch" (Buryat belšer id) is recorded in Old Mongolian Writing as belčir in the same meaning, the archetype of which we can reconstruct as *beltir, as in the development history of sound structure of the Mongolian languages, the syllable *ti developed into či, as a rule, it was in case of borrowing of Turkic words. This Mongolian word in Old Turkic language has a corresponding form beltir "waters meet", well survived in 
Siberian Turkic languages (see the "Comparative-Historical Grammar of Turkic languages...", p. 98, for the existence of this word in Turkic languages).

The vocabulary of inanimate nature involves the names of soils, stones etc. Here it is necessary to consider the Mongolian term čuluu "stone" (Buryat šuluun, Kalmyk čolun id), which can be compared with the Chuvash word čul "stone". At the first sight, this comparison seems to be reasonable, but the etymological analysis shows the ambiguous picture. Thus, the Mongolian word is recorded in the Old Writing as cilayun, the archetype of which is *tilayun, the element-un here is the affix, finalizing the nominal stems in Mongolian languages, and *tilay - is the root. The modern Chuvash čul consistently dates back to the archetype ${ }^{*} t u l$, what is the Bulgar lambdoiding form of the Turkic word taš. Here the Turkic root vowel -a- is consistently replaced by the Bulgar -u-. If to consider, that stone is the oldest material, from which the ancestors of Altaic nations produced their work equipment, then, we can easily assume, that similar names could be survived in Altaic languages, what is indeed so. Thus, the Tungus languages use the word d'oloy to name the stone, and the Korean language uses the word tol. Thus, there is the chain tašl/*tull/*tilay//d'oloy//tol, which testifies about closeness of Altaic languages, relating to the Stone Age epoch (see the "Comparative-Historical Grammar of Turkic languages...", p. 638, for the occurrence of the word taš in Turkic languages and its origin).

The Mongolian bilüü "bar, hone-stone, grinder, grindstone (finely grained grindstone)" (Buryat bülüü "grinder, grindstone, bar, hone-stone", Kalmyk bülü id.) is given in the Old Mongolian Writing as bilegüü, coinciding with the archetype. This word is not etymologized on the Mongolian basis. At the same time, it shall be compared with the Old Turkic bilägü "grindstone", which is formed from the Old Turkic bilä "to grind", what, in its turn, is the derived verb from the Old Turkic bi "blade". See Sevortyan, 1978, p. 142-143, for the occurrence of the form bile in Turkic languages and its Turkic etymology.

The Mongolian khayirya "gravel; pebble, broken stone; sand place; large grindstone, grinder, bar" (Buryat khayir "pebble, broken stone, sandbank, sand spit", Kalmyk khär "shoal, shallow (water)") is recorded in Old Mongolian Writing as qajiryu with the same meaning. This word form falls into two elements: affix - $-\gamma u$ and root qajir, which, the same as Buryat khayir and Kalmyk khär is nothing but the borrowed Old Turkic word qayïr "sand", survived in different modern Turkic languages as qayïr with the meaning "sand, fallow land, soil with pebble" (see the "Comparative-Historical Grammar of Turkic languages...", p. 97; Sevortyan, 1997, p. 217, for the connection of these Turkic and Mongolian word forms, and about their Turkic origin), the verb qaira "to grind on rough stone" is derived from this Turkic root by means of the Turkic affix -a; it produced the derived noun qairaq "rough grind stone", see E.V. Sevortyan (1997, p. 205; the Comparative-Historical Grammar of Turkic Languages..., p. 97).

The Mongolian khom (obsolete) "sand; sandy" (Kalmyk khum rarely "sand, dust") is recorded in Old Mongolian Writing as qom (qum? id). This word obviously corresponds to the Old Turkic qum "sand", which is also widely presented in modern Turkic languages (see the Comparative-Historical Grammar of Turkic Languages..., p. 102). The modern Mongolian khumay "earth; sand grain" and Old Mongolian qumay id., as well as Mongolian khumkhi "sand grain, dust particle; finest particles; molecule, atom; sandy", Buryat khumkhi "dust; sand grain, dust particle", and also Old Mongolian qumaki id. They all date back to the variant qumak of this generally Turkic root (see the Comparative-Historical Grammar of Turkic Languages..., p. 102).

The Mongolian sayir "pebble, small, shivery stone; granitic subsoil" (Kalmyk säär "stony plateau") is recorded in Old Mongolian Writing as sajir id. It can be compared with the Old Turkic saj "volcanogenic stony place; desert plain", survived in some modern Turkic languages with the meaning "pebble place, blind creek, covered with pebble" (see the Comparative-Historical Grammar of Turkic Languages..., p. 93, for the occurrence of this native word in Turkic languages).

The Mongolian toos "dust" (Buryat. tooyon, Kalmyk toosn "dust; dust particle") is given in Old Mongolian Writing as toyusun id., coinciding with the archetype. This word form has two components: toyu and -sun. The component -sun is the general Mongolian affix, formalizing the nouns of not only Mongolian origin, but also borrowed ones, especially from Turkic languages. The component toyu is not etymologized on the Mongolian basis, but coincides well with the Old Turkic toy "dust". When being borrowed, the affix -sun was added to it through the inserted vowel -u-, producing the Old Mongolian word form toyusun.

The Mongolian tovroy "ash, dust, cinder, powder» (Buryat toboroy "ash, dust", Kalmyk tovry "dust particle") is presented in Old Mongolian language as toburay id. This word can be compared with the Old Turkic topraq "earth, ash, dust", which is the derivative from the Old Turkic verb topra= "to wither, to dry" (see the Comparative-Historical Grammar of Turkic Languages..., p. 99, for the occurrence of this word in modern Turkic languages and its Turkic etymology).

The Mongolian balčig "bog, fen, moor, mud, silt" (Buryat balšag "mud; sludge; puddle", Kalm. balčg "slush, mud") is given in Old Mongolian language as balčig id. This word does not have the etymology on the Mongolian basis. It can be correlated with the Old Turkic balčiq, recorded in the Old Turkic language as a part of the pair word balčiq balïq "silt and 
mud" (see the Comparative-Historical Grammar of Turkic Languages..., p. 374-375, for the occurrence of this word in Turkic languages). The Turkic word baliqg//baluq "city" is the single-rooted with the Turkic balčiq, as the ancient Central Asian cities were built up from clay; the associative semantic connection of mud and clay mortar is obviously traced here. Besides, some modern Turkic languages have the word balkaš //balkhaš "slush" (compare, Balkhash lake), which is formed from the root *bal, the same as the abovementioned words (see the Comparative-Historical Grammar of Turkic Languages..., p. 374; Sevortyan, 1978, p. 59, for the Turkic root *bal "clay, slush").

The Mongolian čiig "dampness, moisture, humidity" (Buryat šiig "dampness, moisture, humidity", Kalmyk čiigtä "damp, humid, wet") is recorded in the Old Mongolian Writing as čigig id. This word can be compared with the Old Turkic či "dew; damp, humid" and with the Old Turkic čïq= "to damp, to get wet".

This category of vocabulary involves the names of different water bodies.

The Mongolian dalai "sea, ocean" (compare, Buryat. dalai "sea, ocean; large lake", Kalmyk dälä/l dala "sea, ocean") is recorded in Old Mongolian language as dalai id. It is well compared with the Old Turkic talui in the meaning "ocean, sea". In some modern Turkic languages, mainly Siberian, for instance, Tuvinian, Tofalar, Soyot, the word form dalai "ocean, sea" is presented, where this word, judging by the phonetic structure, is, likely, a mongoloism (see the Comparative-Historical Grammar of Turkic Languages..., p. 89, for the Chinese origin of Turkic word form talui).

The Mongolian tengis "sea" (Buryat tengis in combination with tengis dalai "sea" Kalmyk tengis id) is recorded in Old Mongolian Writing as tengis and can be compared with the Old Turkic tengiz "sea" with devocalization of the final -z.

This general Turkic word is presented in modern Turkic languages in different sound structure, for instance, tengis //deniz//dingez//tines etc. (see the Comparative-Historical Grammar of Turkic Languages..., p. 89 for the Turkic character of this word).

The Mongolian mörön "stream" (Buryat müren id, Kalmyk mörn obsolete "a river that runs into the sea") is recorded in Old Mongolian Writing as mören B in the same meaning. In the language of Old Turkic monuments, it has a corresponding word mürän "river". li is given in the Old Turkic dictionary with the mark Mongolian (see the ComparativeHistorical Grammar of Turkic Languages..., p. 92, for the Turkic character of the word mürän and nostratic origin of its root).

The Mongolian. yol "river" (Buryat qol, Kalmyk yol id) is recorded in Old Mongolian Writing as youl id and can be compared with the Old Turkic qol "valley"(see the Comparative-Historical Grammar of Turkic Languages..., p. 91-92, for the occurrence per nostratic languages).

The Mongolian bulay "spring, well, water source" (Buryat bulay "well, water source, spring", Kalmyk buly "well, water source") is recorded in Old Mongolian Writing as bulay in the same meaning and can be compared with the Old Turkic bulaq "spring, water source"; this word is not etymologized on the Mongolian basis. At the same time, it can be compared with the general Turkic bulut "cloud"; it is possible to assume the origin of these Turkic words from some root *bul= with the semantics "to heave". The image of bubbling spring from under the ground and the image of curling clouds are connected with this semantics (See Sevortyan, 1978, p. 262-264, for the wide occurrence of the word булак in Turkic languages and its Turkic etymology).

The Mongolian khuday "well; pit" (Buryat khuday "well", Kalmyk khudy id) is recorded in Old Mongolian Writing as quduy in the same meaning. This word is not etymologized on the Mongolian basis, but it can be compared with the Old Turkic quduy "well". This word form correlates with the word forms quסuy and qujuy "well", presented in different Old Turkic languages. The form quduy dates back to the Old Turkic $d$-language, represented by the Old Uigur and Old Oguz languages. It is based on the Old Turkic verb qud= "to pour", which is based on the consonant $-d-$, alternating with $-z-/ /-j-$ II-r- in Turkic languages (compare, Old Turkic quס=, quj= "to pour").

The Mongolian aday "delta, inflow, lower reach, domain", having also the meaning "end, bottom line; low; extreme, uttermost, worse, useless, bad (in quality)" (Buryat aday "end; inflow; figurative the last, the worse, bad" Kalmyk ady id) is recorded in Old Mongolian Writing as adag with the same meanings. The same as with the Mongolian khuday, this lexeme shall be compared with the Old Turkic adaq "foot; leg; support; bottom part, foundation; inflow", which has a consonant $-d$ - in its stem in the place of $-z-\| /-j-l /-r$ - of other Turkic languages. This feature allows referring this word to Old Uigur or Old Oguz (compare in other Old Turkic languages aסaq, ajaq); see Sevortyan, 1974, p. 104-105, for the occurrence of this lexeme in Turkic languages and its original character).

The Mongolian aral "island" (Buryat aral, Kalmyk arl id) is recorded in Old Mongolian Writing as aral id. This word can be correlated with the Turkic aral "island", where the general Turkic root ara "interval, space between" can be traced; it explains the position of island among the water bodies (see Sevortyan, 1974, p. 167, for the existence of this word in Turkic languages and variants of its etymology).

The Mongolian oltrig "archipelago, island, islet" (Buryat oltirog id) is recorded in Old Mongolian Writing as olturig id, and can be correlated with the Old Turkic otruy "island". 
The inanimate nature also involves natural phenomena, elements, nature, downfall, time, celestial sphere etc. Let us consider Mongolian terms, included into this group, more thoroughly.

The Mongolian oč "spark" (Buryat ošon, Kalmyk očn id) is recorded in Old Mongolian Writing as očin id, dating back to the archetype *otin through the form*otin; it is not explicable on the Mongolian basis. However, this word can be decomposed into two constituents: the element ot and ïn, which can be interpreted as the indicator of the nominal stems, also joined to the borrowed words, and the element ot is nothing but the borrowed Old Turkic word ot "fire". This word is the general Turkic one, and it is wide spread in all modern Turkic languages. The association of flying sparkles of the burning fire with the fire itself makes this presupposition probable (see Sevortyan, 1974, p. 483-484, for the wide occurrence of this word in Turkic languages).

The Mongolian zali "flame, shine" (Buryat sog zali "fervency", zali tümer "coal tongs", Kalmyk zali "flame") is recorded in Old Mongolian Writing as jalin id, having the archetype *jalïn, which can be correlated with the Old Turkic jalin "flame", derived from the Old Turkic verb ja=l "flash, inflame". This Turkic word was also included to the Old Mongolian language with the initial consonant 3 - instead of $y$-; we can see it is some modern Turkic languages, such as Kirghiz, Kazakh and some Siberian (see Sevortyan, 1989, p. 106-107, for the wide occurrence of this word in Turkic languages and its etymology).

The Mongolian cog "gleed; fever, cinder" (Buryat sog "smouldering coal", Kalmyk cog "fever") is recorded in Old Mongolian Writing in the form of čoy id, corresponding to the Old Turkic čoy "glitter, shine; flame, fever".

The Mongolian salkhin "wind" (Buryat khalkhin, Kalmyk salikn id) is recorded in Old Mongolian Writing in the form of salkin id, having the archetype *salqïn. In Old Turkic language, it has a corresponding word form salqiin "coolness, cold", wide spread in this meaning in modern Turkic languages (see the Comparative-Historical Grammar of Turkic Languages..., p. 16, 43, for the occurrence of this word in Turkic languages). It is possible, that the lexeme salqiin with the meaning "wind", existing in Siberian Turkic languages, appeared there under the Mongolian impact. The metaphorical adjacent transfer is traced here, as cold and coolness in steppe treeless area are always connected with wind.

The Mongolian boroo "rain" (Buryat boroo "rain", Kalmyk boran "foul weather, bad weather, rain") is recorded in Old Mongolian Writing in the form of boruyan id. In the form, this word is close to the Turkic word form borayan, which is presented by E.V. Sevortyan for some modern Turkic languages together with the form boran with the meaning "windstorm, foul weather, driving rain" and presupposes the Turkic verb bora= "to dust, to whirl up; to blow hard; to storm" in the basis of these words; its genesis presupposes the Turkic bor "windstorm" (1978, p. 189-191).

The Mongolian zad "foul weather, bad weather; bewitchment, faery; a way to blow up foul weather with magic charms" (Buryat zada "foul weather, bad weather", Kalmyk zad id) is recorded in Old Mongolian Writing as jada id. It can be correlated with the Old Turkic jat "bewitchment, fairy, connected with blowing up wind and rain".

The Mongolian zud "dzut, ice-crusted ground, fodder shortage" zud turkhan "fodder shortage" (Buryat zud "icecrusted ground, fodder shortage from the ice-crusted ground", Kalmyk zud «dzut, ice-crusted ground, fodder shortage") is recorded in Old Mongolian Writing in the form of jud id, which corresponds to the Old Turkic jut "ice-crusted ground, causing animal death". Thus Turkic form is presented in different modern Turkic languages as yut//̌ut/žut//cuut, basically, with these meanings; thus, Turkic origin of this Mongolian word form is stated (Sevortyan, 1989, p. 256-257).

The Mongolian šuurya "windstorm, severe snowstorm, winter storm; storm; hurricane; snowstorm; tornadic" (Buryat šuuryan "storm", Kalmyk šuuryn "windstorm, winter storm, severe snowstorm") is recorded in Old Mongolian Writing as šiyuryan id; it dates back to the archetype *sïyuryan. Two components are traced here: the root *sïyur and -yan, which is the Mongolian word-forming affix. The component *sïyur can be compared with the Turkic verb sïyir= "cwhistle, sound about whistle", presented in some modern Turkic languages (see the Etymological Dictionary of Turkic languages, 2003, p. 384-387, for the occurrence of this word in Turkic languages), for instance, in Tofalar, which has the verb siipiir "to whistle", the genesis of which has the onomatopoetic root sï and affix - yïr/-kïr, forming the verbs from the onomatopoetic roots in Turkic languages. The formation of names of windstorm, winter storm, severe snowstorm, storm from the verb "to whistle" is quite explainable by the fact, that the storm is always accompanied by the wind whistle that is why the associative connection of storm and wind whistle is traced here.

The Mongolian khäruu "frost" (Buryat khüruu, Kalmyk kirüü id.) is recorded in Old Mongolian language as kirayu id, the archetype of which is *qïrayu, which obviously corresponds to the Old Turkic qïrayu "frost, frost-mist". This Turkic word form is presented in many modern Turkic languages, its Turkic origin is stated for Mongolian languages (the Comparative-Historical Grammar of Turkic Languages..., 2001, p. 36-37).

The Mongolian kharankhui "darkness; obscurity, dark" (Buryat kharankhii, Kalmyk kharnyu id) is recorded in Old Mongolian language as qaranyui id, corresponding to the Old Turkic qaranyu id. Undoubtedly, the Mongolian and Turkic forms here are derived from the Turkic-Mongolian root qara "black", widely spread both in Mongolian and Turkic languages (see the Etymological Dictionary of Turkic languages, 1997, p. 286-288, 299-301, for the occurrence of this 
word and its etymology in connection with kara).

The Mongolian cag "time; period; hour; clock» (Buryat sag "time, period", Kalmyk cag "time, period") is recorded in Old Mongolian language as čay id, what is quite corresponding to the Old Turkic čaq "time, period". This word is widely spread in modern Turkic languages in the same meaning (see the Comparative-Historical Grammar of Turkic Languages..., 2001, p. 67-68, for the occurrence of čaq in Turkic languages and its connection with the Mongolian čay).

The Mongolian žll "year" (Buryat žel, Kalmyk žil id) is recorded in Old Mongolian language as j̈ll id, the archetype of which is jil, corresponding to the Old Turkic jïl "year". This word is widely spread in modern Turkic languages as yiil//yil//il//žil//žill//čil etc. (see the Comparative-Historical Grammar of Turkic Languages..., 2001, p. 79-71; Sevortyan, 1989, p. 275, for the occurrence of this word in Turkic languages and its Turkic character in Mongolian language).

The Mongolian tenger "sky, heavens, heavenly sphere" (Buryat tengeri, Kalmyk tengr «sky, heavens") is recorded in Old Mongolian language as tngri id, corresponding to the Old Uigur orthography of this word. In the language of Old Turkic runic monuments, it has a corresponding form tänri "sky; god, deity; godlike; sovereign, lord", which is presented in many modern Turkic languages either with the meaning sky, or with the meaning deity; there is also a hypothesis about its origin from the Old Turkic verb ten= "to dominate, to raise, to fly up" (see the Comparative-Historical Grammar of Turkic Languages..., 2001, p. 59), although it is replaced by the word asman "sky" in Turkic nations with Muslim religion.

The Mongolian colmon "Venus" (Buryat Солбон id) is recorded in Old Mongolian language as čolmon id, corresponding with the Turkic word colpan "Venus", which is presented in many modern Turkic languages (see the Comparative-Historical Grammar of Turkic Languages..., 2001, p. 50-51, for its occurrence in Turkic languages and its Turkic origin).

\section{Conclusions}

The Mongolian terms of inanimate nature, considered above, having the Turkic parallels mainly in Old Turkic language, the monuments of which are many centuries older, than the monuments of Old Mongolian language, speak about the fact, that these terms existed in Mongolian languages long before the decay of Mongolian ethnic community and formation of Buryat, Khalkha-Mongolian and Oyrat areas. Turkic etymologies, in many cases, provide an opportunity to assume easily the Turkic origin of these Mongolian terms, characterizing this place, its landscape peculiarities, soil type, specificity of climate, atmospheric phenomena, celestial sphere etc.; as these terms obviously have the Turkic etymology, then it testifies about originality and inclusion of the whole layer of Turkic words to the vocabulary system of Mongolian language; apparently, they refer to the substrate language, which replaced the language of local Turki; such mixture processes of Turkic and Mongolian ethnic groups took place repeatedly during the historical development of Turkic and Mongolian nations.

\section{Summary}

Thus, this lexico-semantic group, including the variety of obvious originally Turkic words, testifies about complex composition of vocabulary of modern Mongolian languages and its hybrid character.

\section{Acknowledgements}

The Research is accomplished with financial support from Russian Foundations for Humanities-Min. of Cultural Property of Mongolia under the scientific investigations "Turkic-Mongolian lexical Commonness, as a Result of Relations of Turkic and Mongolian Ethnic Groups", project \# 14-24-03003a (m).

\section{References}

Baskakov, (1981). Altaic language family and its study. Moscow.

Vladimirtsov, B.Ya. (1911). Turkic elements in Mongolian language. West-East Department of IRAS, St. Petersburg, XX, II-III.

Golstunsky, K.F. (1894-1898). Mongolian-Russian dictionary (amendments). St. Petersburg, I-III, IV.

Old Turkic dictionary (1969). Leningrad.

Kalmyk-Russian dictionary (1977). Moscow.

Kovalevsky, O. (1844-1849). Mongolian-Russian-French dictionary. Kazan, I - III.

Kotwich, V.L. (1962). The Studies on Altaic Languages. Moscow.

Ramstedt, G.I. (1957). Introduction to Altaic linguistics. Morphology. Moscow.

Rassadin, V.I. (2007). Essays on development history of Turkic-Mongolian language community. Part I. Turkic impact on the vocabulary 
of Mongolian languages. Elista.

Rassadin, V.I. (2008). Essays on development history of Turkic-Mongolian language community. Part II. Mongolian impact on the vocabulary of Turkic languages. Elista.

Rassadin, V.I. \& Trofimova, S.M. (2012). The correlation of Mongolian and Turkic grammar elements as a part of Turkic-Mongolian language commonness. Elista.

Rona-Tash, A. (1974). Is there the general heritage or borrowing? (To the problem of relations of Altaic languages). The Problems of Linguistics, 2.

Rasyanen, M. (1955). The materials on historical phonetics of Turkic languages. Moscow.

Sanzheev, G.D. (1947). To the Turkic-Mongolian linguistic problem. The Works of Moscow Institute of Oriental Studies, Moscow, 4.

Sanzheev, G.D. (1971). To the problem of Turkic borrowings in Mongolian languages. Linguistic Collection, Tashkent.

Sanzheev, G.D. (1973). About Turkic-Mongolian linguistic parallels. Soviet Study of Turkic Languages, 6.

Sevortyan, E.V. (1974). Etymological dictionary of Turkic languages (General Turkic and Inter-Turkic stems in vowels). Moscow: Nauka.

Sevortyan, E.V. (1978). Etymological dictionary of Turkic languages (General Turkic and Inter-Turkic stems in "B" letter) (pp. 142-143). Moscow: Nauka.

Comparative-historical grammar of Turkic languages. Vocabulary (2001). Moscow: Nauka.

Suyunchev, Kh.I. (1977). Karachay-Balkar and Mongolian lexical parallels. Cherkessk.

Sydykov, S. (1966). Turkic-Mongolian parallels. The formation sources of Turkic languages of Central Asia and South Siberia. Frunze.

Sydykov, S. (1983). Mongolian-Turkic lexical parallels. Frunze: llim.

Cheremisov, K.M. (1973). Buryat-Russian dictionary. Moscow.

Shcherbak, A.M. (1959a). About the character of lexical relations of Turkic, Mongolian and Tungus languages. The Problems of Linguistics, 3.

Shcherbak, A.M. (1959b). About Altaic hypothesis in linguistics. The Problems of Linguistics, 6.

Shcherbak, A.M. (1960). About the research procedure of linguistic parallels (in connection with Altaic hypothesis). Moscow.

Shcherbak, A.M. (1977). Early Turkic-Mongolian linguistic connections (7-13 centuries). St. Petersburg: ILI RAS.

Shcherbak, A.M. (2005). Turkic-Mongolian language contacts in the history of Mongolian languages. St. Petersburg.

Etymological dictionary of Turkic languages. General Turkic and Inter-Turkic stems to "Ж", З̌ "Ж"("З") and "Й"("") letters (1989). Moscow: Nauka.

Etymological dictionary of Turkic languages. General Turkic and Inter-Turkic stems to "K" and "Қ" Q letters (1997). Moscow: Nauka.

Etymological dictionary of Turkic languages. General Turkic and Inter-Turkic stems to "Л"("L"), "M"("M"), "H"("N"), "П"("P"), "C"("S") letters (2003). Moscow: Oriental Literature of RAS.

Doerfer, G. (1963). Türkische und mongolische Elemente im Neupersischen. Bd. 1. Wiesbaden.

Kotwich, W. (1950). Studia nad jezykami altaiskimi. RO, XVI.

Kotwicz, W. (1953). Rocznik orientalistyczny. Tom XVI (1950). Krakow.

Lessing, F.D. (1960). Mongolian-English Dictionary. Berkley and Los Angeles.

Poppe, N. (1960). Vergleichende Grammatik der Altaischen Sprachen (pp. 188). Teil 1. Vergleichende Lautlehre. Von Nikolas Poppe, Otto Harrassowitz- Wiesbaden.

Poppe, N. (1965). Introduction to Altaic Linguistics. Otto harrassowitz. Wiesbaden.

Ramstedt, G.J. (1965). Einführung in die altaische Sprachwissenschaft. Helsinki.

Räsänen, M. (1965). Über die ural-altaische Sprachwissenschaft. Helsinki. 